\title{
The Communication Patterns of Leadership in Improving Work Ethic of Lecturer and Staff in Asahan University (Islamic Communication Perspective)
}

\author{
Dailami $^{1}$, Syukur Kholil ${ }^{2}$, Lahmuddin Lubis ${ }^{2}$ \\ ${ }^{1}$ Ph.D Student in State Islamic University of North Sumatera (UINSU), Medan, Indonesia \\ ${ }^{2}$ Lecturer in State Islamic University of North Sumatera (UINSU), Medan, Indonesia \\ dailamidai2@gmail.com
}

\begin{abstract}
This study aims to analyze the communication patterns of leadership in improving work ethic of lecturer and staff, the implementation of leadership communication patterns to the principles of Islamic communication and to identify various barriers occurring at Asahan University. The research method used in this study is a descriptive method through a qualitative approach, by observing the state of the subject or object of research at the time of the study based on the events that are seen. The results of research carried out show the communication patterns of leadership in improving work ethic of lecturer and staff through vertical patterns, horizontal patterns and diagonal patterns. Whereas the implementation of Islamic communication Principles at Asahan University are Qaulan Sadīdā, Maīysūrā Qaulan, Ma'rūfä Qaulan, Layyinā Qaulan, Karīma Qaulan and Baligha Qaulan. Barriers in improving work ethic of lecturer and staff include mental attitude, primordial relation, welfare levels and improper placement of work fields.
\end{abstract}

Keywords

leader communication patterns,

work ethic, lecturers and

employees Asahan Uhiversity,

Islamic communication

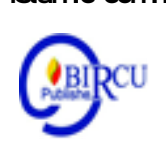

\section{Introduction}

Work ethic is an important part and determinant of success for individuals, groups, institutions and even broader in a nation in achieving its goals. Work ethic is an attitude that arises out of one's own will and awareness based on a system of cultural values orientation towards work. Ethos comes from Greek, which is ethos which means attitude, personality, character, character, and belief in something. This attitude is not only shared by individuals, but also by groups, even society. Ethos is formed by a variety of habits, cultural influences, and value systems that it believes.

The ability to live the work becomes very important as an effort to create excellence. In essence, when we do a job, in essence we are doing a service process. Living the work as a service requires its own capabilities that are beyond the small space of human movement. This can all be seen and stated in the work ethic of lecturers and staff at Asahan University.

Asahan University, which was established 34 years ago, located in Kisaran City, Asahan Regency, is an institution of pride for its people as well as people in other regions who are proud of universities whose identities carry the name of the region. The ups and downs that have been passed by Asahan University in its journey to face maturity seems to be tested with various challenges that hit, if it is successful, it is possible that Asahan University will become a well-known tertiary institution in the East Coast region of North Sumatra. 
As a higher education organization always strives to create a good working relationship between leaders and subordinates, in maintaining this condition a leader who can exert influence and can foster a work ethic of subordinates at work, so that his performance is more leverage. In the application of leadership communication, leaders can communicate with various types of leadership communication in accordance with the selection of communication patterns. The type of leadership communication must be owned by a leader for the leader to use in influencing his subordinates to achieve organizational goals. Since being sworn in as Asahan University Chancellor in 2017, Ibnu Hajar of Asahan's son is likened to returning to his hometown to improve tertiary education in his birthplace, it's only natural to have the experience of capturing State University of Medan some time ago, he devoted to reforming in various fields with one commitment Acceleration of Change towards Superior Asahan University.

In Islamic teachings, office position is seen as a mandate from Allah SWT, therefore the mandate received must be accountable. Then to be able to successfully carry out the mandate given to him, the Chancellor of Asahan University as a new leader must know how the communication that must be applied to the entire academic community so that the messages conveyed are able to foster active participation, especially in realizing the vision and mission and Tri Dharma of Higher Education, it is important that Asahan University as an organization can run according to the desired motion, especially to achieve the goals or targets to be achieved in the future, making Asahan University as a superior university to be equal to other leading universities.

Work ethic is an attitude that arises from the will and self-awareness based on a system of cultural values orientation towards work. The origin of the word ethos is taken from Greek, ethos which means personality, attitude, character, character, and belief in something. Ethos is formed on a variety of habits, cultural influences, and value systems that are believed.

The general condition of the work ethic in Asahan University environment seems not yet ready to accept the drastic changes that are applied due to various causes that directly influence such as the level of education and skills of employees, employee experience, strong kinship relations, relatively low employee welfare, lecturer education levels, lecturer welfare, ranks of lecturers, infrastructure and so on, all of which greatly affect the work ethic of employees and lecturers at Asahan University.

An answer is needed to realize the hopes of those who want change to improve for the better, as well as how to ward off the pessimism that lasted for a long time waiting for Asahan University to develop and be more advanced. The question is, can the chancellor as the new leader bring the hopes of many parties in realizing the wishes of the community, including Asahan University academic community, through the communication he does.

\section{Review of Literature}

\subsection{Communication Patterns}

There are three types of formal communication in organizations, namely: horizontal vertical communication and diagonal communication. (Gibson.1997) 


\section{a. Vertical Pattern}

Communication that occurs between superiors and subordinates. According to Robbins vertical communication is communication that flows from one level in an organization / group to a higher level or lower level reciprocally.

\section{b. Horizontal Pattern}

The form of horizontal communication in which the exchange of messages occurs sideways and is carried out by two parties who have the same position, same position, level position, and the same echelon in an organization.

\section{c. Diagonal Pattern}

According to Koontz this cross communication does not follow the organizational hierarchy but cuts the command line. This communication occurs from one party to another party in a different position, where the two parties are not on the same structural path. Diagonal communication is used by two parties who have different levels but do not have direct authority to the other party.

\subsection{Organizational Communication}

The organization is a system implemented by people who work together to achieve a common goal, be it in rank or division of labor. Communication in organizations becomes important to create a common understanding of the information conveyed to one another.

\subsection{Work Ethics}

Ethos is a term taken from the Greek "ethos" which contains the meaning of character, moral character, habits or moral goals of a person as well as their world perception, that is, the most comprehensive picture, way of acting or ideas about order. The work ethic of lecturers is elaborated on the competence and activities of lecturers, a form of working ethically or working well in tertiary institutions. While the employee work ethic is closely related to personality, behavior and character as a guarantor of work results with better quality by opening communication or connections between fellow employees, increasing awareness and adjustment, increasing quality, efficiency and effectiveness so as to minimize errors in work .

\subsection{Principles of Islamic Communication}

In this case, the researcher refers to specific terms that are assumed to be explanations of the principles of communication.

1. Qaulan Balighā (Meaningful communication)

2. Qaulan Mā̄ysūrāa (Easy Communication)

3. Qaulan Ma'rüfā (Good Value Communication)

4. Qaulan Layyinā (Gentle Communication)

5. Qaulan Karima (Pleasant Speech)

6. Qaulan Sadìdā (Decisive Communication) 


\section{Research Method}

In determining the method of this study, researchers conducted a descriptive method. The stages of the research method of this research are as follows. Data analysis is the process of simplifying data into a form that is easier to read and present. This research is descriptive in nature, namely research that has a picture of situations or events. The process of collecting data includes three pathways namely data reduction, data presentation and drawing conclusions.

\section{Discussion}

\subsection{General Findings}

Asahan University Foundation was founded on July 18, 1985 with the Deed of Establishment Number 41 issued by Notary Dr. Adiputra Parlindungan. Asahan University Foundation where its establishment was initiated by H. Zulfirman Siregar (Regent of Asahan at the time) with the support of community components who saw that the conditions of the society of Asahan Regency and students in particular were still lagging behind some other regions in North Sumatra Province in the field of education especially tertiary education.

Since its establishment in 1985, Asahan University has always tried to increase the number and quality of its lecturers. Until the end of October 2019, the number of lecturers at Asahan University reached 124 lecturers consisting of 26 lecturers from Faculty of Engineering, 22 lecturers from Faculty of Agriculture, 22 lecturers from Faculty of Economics, 16 lecturers from Faculty of Law and 38 lecturers from Faculty of Teacher Training and Education. Regarding the number of teaching staff based on lecturer status (permanent lecturers and DPK), while the number of teaching staff is 87 people.

\subsection{Leadership Communication Patterns in Improving Work Ethics of Lecturers and Staff at Asahan University}

\section{a. Vertical Communication}

\section{1) Communication of superior with subordinate}

In the case of communication between superiors and subordinates, all leaders conduct vertical downward communication as is done by the Chancellor of Asahan University, according to the chancellor as usual and is normal when notifying about a meeting to be held, usually there will be instructions given to subordinates. "The form of communication that I apply in delivering written messages to subordinates is through letters, sometimes directly, sometimes through extension to all my subordinates."

2) Communication of subordinate with superior

Communication between subordinates and superiors takes place at the academic community at Asahan University. As the Lecturer in Faculty of Economics Hilmiatus Sahla said in a few weeks the internal faculty will hold evaluation meetings and monitoring meetings. "Opinions or suggestions that I put forward in official meetings are recorded but to be taken into consideration in making decisions by leaders in the environment faculty.

\section{b. Horizontal Communication}

Horizontal communication usually does not exist in the design of an organization, therefore, leaders have full authority in implementing it. Communication between colleagues 
is often needed to coordinate and can also meet the needs of the community. As informant Ratna Ningsih, an employee of the Faculty of Economics, "I often address the problem directly to the vice dean and dean who are my superiors, including the occasional co-worker in the same environment".

\section{c. Diagonal Communication}

Diagonal communication at Asahan University occurs when several parts are involved in the same program and the fact that all programs at Asahan University always involve more than one section. The form of communication in the program planning process is to invite meetings, consultations, synchronize schedules, remind schedules, and exchange information or data. This is in accordance with the statement from informant R. Mitro Kuntjoro Kabiro Bapsi "For activities that require many work units to be involved for the success of our university program, we conduct communication across work units so that the program can achieve maximum results".

\subsection{The Implementation of Leadership Communication Patterns to the Principles of} Islamic Communication in Improving Work Ethics of Lecturers and Staff at Asahan University

In Islamic teachings there are principles in building effective communication. The principle of effective communication can be seen in Qur'an. The principles of effective communication are: Ma'rufa Qaulan, Sadida Qaulan, Baligha Qaulan, Karima Qaulan, Maisura Qaulan, Layyina Qaulan.

The whole principle of Islamic Communication, can foster the work ethic of lecturers and employees at Asahan University, this was done by the Rector of Asahan University in a meeting with subordinates and staff with the principle of Layyanina Qaulan. "I conveyed a gentle message to lecturers and employees at inter-work meetings in the work environment of Asahan University." said the informant Ibnu Hajar the chancellor to researchers.

\subsection{The Barriers in Communication Patterns of Leadership at Asahan University}

Barriers to communication patterns of leaders at Asahan University include primordial ties, welfare levels, inappropriate placement of work fields and mental attitudes, all of which are very influential, as stated by informant Amir Hamzah Dean of the Faculty of Engineering "Can be a barrier to communication, because these factors make it difficult to enforce discipline, in my opinion it is an barriers because they are difficult to obey the rules and even the impact can affect the work performance of lecturers and staff", the informant told the researchers.

\subsection{Special Findings}

The first finding, this study found the efforts of leaders at Asahan University in establishing an atmosphere of communication, that overall leaders functioned as subordinates who became structural in their respective work units according to their field of work both at the foundation, rectorate level, including in the faculties. This effort makes the vertical communication pattern work as it should, not limited when the leader is in place especially when not in the work environment.

Another form of efforts to build a communication climate is that the leadership is open to various criticisms regarding policies issued on various matters that may not or are not suitable according to the evaluation of subordinates. As the informant Ely Ezir conveyed "To 
the criticism conveyed by lecturers and staff regarding policies that they value is not in their favor, I made the criticism an effort to improve, I opened the opportunity to have a dialogue", said the Dean of the Teaching and Education Faculty.

Second Findings, this study found that communication channels using social media have an important role in delivering informal messages, even social media in the form of Whatsapp seems to be an official communication channel because it is more often used in the delivery of various work activities and activities such as meeting invitations, announcements and others forth in the form of letters, is widespread through these social media channels. Asahan University as an organization engaged in the organization of tertiary education, in improving a climate of communication between leaders and subordinates, it turns out that it is not limited to the media of correspondence or verbal, because at Asahan University there are also Whatsapp groups and Facebook groups for informal communication platforms.

The presence of Whatsaapp group at Asahan University was in fact able to overcome or simplify the communication hierarchy between officials and subordinates in the context of communication, this was acknowledged by the Rector of the Asahan University.

"Conveying messages through social media Whatsapp group is very helpful and useful in communicating in all directions both to the structural in the teaching staff and education staff at the top and bottom level about the problems that occur at the university", said Ibnu Hajar and a number of other leadership elements at Asahan University.

The third finding, this study found that the principles of Islamic communication which are effective communication, became an inseparable part of the leadership's communication in improving the work ethic of lecturers and staff at Asahan University, regardless of whether the leader previously knew the terms about the principles of Islamic Communication or not, but what the researchers found was that some of the leaders admitted that they only knew the term Islamic Communication Principles, although some of them were not familiar with the term, but they had practiced it so far in work activities in the work environment of Asahan University.

Regarding the implementation of leadership communication with these Islamic Communication Principles, as stated by the Chairperson of the Asahan University Foundation

"In communicating formally or informally as a leader, I rarely quote verses from the

Qur'an and Hadith, although that can be an important part of reinforcing the message that I convey to lecturers and staff in the university work line. I realize that the application of the principles of Islamic Communication in conveying various messages in the university work environment can open the minds and acceptance of subordinates," said Mapilindo

The fourth finding, this research shows that in general the work ethic of all employees in Asahan University is still not encouraging, but for lecturers, their work ethic is starting to show improvement although it still needs improvement. Regarding the work ethic of employees who have not met expectations directly affect the performance they show, based on the observations of researchers, this problem is caused because in the period of time before the leadership of the Rector of Asahan University, Ibnu Hajar, the condition of the work ethic was less of a concern. The employee at that time was accustomed to routine in carrying out work, so the problem of work ethic was felt by the new leadership of the current university, like it or not, like it or not, he had to face reality because it was part of his responsibility to reform. 
From field data through interviews and observations, the level of welfare received by lecturers and staff is relatively minimal, conditions that occur are possible because the foundation's financial capacity has not been sufficient to provide welfare after the minimum standard of living needs. Regarding the issue of the level of welfare received, such as the response stated by informants, Journalists

"I do work based on awareness and responsibility, because I feel the work is done as a commitment as an employee at Asahan University. Whereas regarding welfare is accepted, so far it is not appropriate because in my opinion a harmonious working atmosphere alone is still not enough to create a work spirit without being accompanied by an adequate level of welfare," said this Faculty of Economics KTU.

The fifth finding, this study also found that commitment to change towards superior Asahan University contained in the vision and mission of Asahan University was an effort to achieve Asahan University progress from current conditions such as the expectations of many academics and the Asahan community and surrounding areas so that Asahan University would progress in various fields such as universities others who have made progress, to achieve excellence is not an easy job, especially if there are many limitations such as work ethics, infrastructure, availability of lecturers, lecturer education, lecturer research, employee skills, university governance and various things that become variables determinant to achieve these advantages.

Regarding optimism Asahan University will be able to become a superior university as the target described above was conveyed by Agus Salim's informant "Knowing and understanding the targets conveyed by the leadership of the socialization towards efforts to create Asahan University superior, optimistic what our wishes and hopes from all education staff can be achieved", said this Academic Kabiro.

\section{Conclusion}

Vertical communication patterns are generally carried out at Asahan University in the context of formal communication both from superiors and subordinates, and horizontal communication patterns are carried out in an effort to build harmony among fellow leaders in Asahan University in the context of informal communication. While diagonal communication patterns occur when several parts are involved in the same program and the fact that all programs at Asahan University always involve more than one part.

The implementation of leadership communication patterns towards the principles of Islamic communication in improving the work ethic of lecturers and staff at Asahan University. The six principles in Islamic Communication as a whole are seen in the communication situation delivered by leaders at Asahan University such as Qaulan Sadida regarding the overall work related to Tupoksi, While Qaulan Ma'rufa was delivered by the leader to lecturers and employees through an appeal to improve services to students in various affairs at the university or faculty level. While Qaulan Baligha delivered the leader at the direction of monitoring and evaluation in the ranks of the university to lecturers and employees at Asahan University. The Principle of Islamic Communication Qaulan Layyina was conveyed by the leader to lecturers and staff on the occasion of inter-work meetings in the work environment of Asahan University, besides Qaulan Karima, the leader conveyed it enthusiastically by growing motivation to lecturers and employees in the work environment of Asahan University, while the principle Finally Qaulan Masyura delivered the leader by 
choosing words using the language of expression and parables in delivering it to lecturers and staff in the work environment of Asahan University.

At Asahan University there are four barriers to communication patterns of leaders that must be considered including primordial ties in the form of family relations and kinship to be a common condition in the work environment of Asahan University, each personnel has ties to each other. The way to handle it is that the leader sticks to the rules. The level of welfare of staff and lecturers, both educators and education personnel receive relatively minimal salaries, classified under the minimum wage provision. This condition is indeed the barriers especially in the seriousness of the work done. Welfare provision aims to encourage work productivity and peace of mind for lecturers and employees. The placement of the work field is not appropriate because most of the education personnel only a small portion occupy the work field in accordance with the abilities of their scientific backgrounds. Mental barriers assess work as a routine, including working on the orders of the leader. To overcome these mental attitude barriers, leaders at Asahan University always invite lecturers and educational staff to be serious in their respective fields of work by carrying out various training in stages.

\section{References}

Amir Hamzah, Dekan Fakultas Teknik, wawancara di Kisaran, tanggal 25 Oktober 2019

Daft, L Richard. (2003). Management. Jakarta: Salemba Empat Djatmiko.

Ferry Novliadi. (2009). Hubungan antara Organization Based Self Esteem dengan Etos Kerja, (Medan: Skripsi Tidak Diterbitkan)

Gibson, J. L. et al. (1997). Organisasi dan Manajemen. Jakarta; Penerbit Erlangga.

Hayati ,Yayat. (2004). Perilaku Organisasi. Bandung: Alfabeta

Hilmiatus Sahla, Prodi Ekonomi PembangAsahan Universityn, wawancara di Kisaran, tanggal 1 Nopember 2019

Ibnu Hajar, Rektor Universitas Asahan, wawancara di Kisaran, tanggal 23 Oktober 2019

Koontz, Harold, Cryl O' Donnell, (1989), Manajemen, Edisi Kedelapan, Alih bahasa Antarikso, Jakarta: Penerbit Erlangga

Qur'an Asahan University, Edisi Khusus Wisuda 06 April 2019

R. Mitro Kuntjoro, Biro Rektor, wawancara di Kisaran, tanggal 1 November 2019

Ratna Ningsih Butar-butar, Fakultas Ekonomi Asahan University, wawancara di Kisaran, tanggal 22 Oktober 2019

Robbins, Stephen P. (2001). Perilaku Organisasi: Konsep, Kontroversi, Aplikasi, Jilid 1, Edisi 8, Jakarta Prenhallindo

Soemirat Soleh, dkk. (2009). Komunikasi Organisasional, (Jakarta: Universitas Terbuka,), Modul Kuliah

Sukardewi, Nyoman, et. all. 2013. Kontribusi Adversity Quotient (AQ) Etos Kerja dan Budaya Organisasi terhadap Kinerja Guru SMA Negeri di Kota Amlapura. Jurnal Akuntansi Pascasarjana Universitas Syiah Kuala, volume 4. 